\title{
Pathogenesis of Campylobacter fetus Infections

\author{
Role of Surface Array Proteins in Virulence in a Mouse Model
}

\author{
Zhiheng Pei and Martin J. Blaser \\ Medical and Research Services, Veterans Administration Medical Center, and Division of Infectious Diseases, \\ Department of Medicine, University of Colorado School of Medicine, Denver, Colorado 80220
}

\begin{abstract}
We developed a mouse model to compare the virulence of Campylobacter fetus strains with (S-plus) and without (Sminus) surface array protein (S-protein) capsules. In adult HA/ICR mice pretreated with ferric chloride, the $\mathrm{LD}_{50}$ for S-plus strain 84-32 was 43.3 times lower than its spontaneous S-minus mutant 84-54. Seven strains of inbred mice were no more susceptible than the outbred strain. In contrast to the findings with Salmonella typhimurium by others, $3 \times 10^{7} \mathrm{CFU}$ of strain 84-32 caused $90 \%$ mortality in $\mathrm{C} 3 \mathrm{H} / \mathrm{HeN}$ (LPS ${ }^{n}$ ) mice and $40 \%$ mortality in $\mathrm{C} 3 \mathrm{H} / \mathrm{HeJ}\left(\right.$ LPS $^{\text {d) }}$ mice. High-grade bacteremia in HA/ICR mice occurred after oral challenge with S-plus $C$. fetus strains and continued for at least $2 \mathrm{~d}$, but was not present in any mice challenged with $\mathrm{S}$-minus strains. Bacteremia at 30 min after challenge was 51.6-fold lower in mice pretreated with $10 \mu \mathrm{l}$ of rabbit antiserum to purified S-protein than after pretreatment with normal rabbit serum. Challenge of mice with a mixture of S-minus strain 84-54 and free S-proteins at a concentration 31.1-fold higher than found in wildtype strain 84-32 caused $30 \%$ mortality, compared with $0 \%$ with strain 84-54 or S-protein alone. These findings in a mouse model point toward the central role of the S-protein in the pathogenesis of $\boldsymbol{C}$. fetus infection. The S-protein is not toxic per se, but enhances virulence when present on the bacterial cell surface as a capsule. (J. Clin. Invest. 1990. 85:10361043.) surface array proteins $\bullet C$. fetus animal model $\bullet C$. fetus infection $\cdot C$. fetus bacteremia $\cdot C$. fetus virulence factor
\end{abstract}

\section{Introduction}

Campylobacter fetus subspecies fetus is recognized in humans as an opportunistic pathogen causing systemic infections in immunocompromised hosts (1-4). Recent reports indicate that $C$. fetus also causes diarrhea and suggest that the intestinal tract may be its portal of entry into the bloodstream (5). Although the mechanisms by which $C$. fetus causes systemic infection have not been defined, several in vitro studies indicate that a surface array protein (microcapsule) in wild-type $C$. fetus strains plays a critical role in the organism's ability to resist both the complement-mediated bactericidal activity in

The current address of Dr. Pei and Dr. Blaser is Division of Infectious Diseases, Department of Medicine, Vanderbilt University School of Medicine, Nashville, TN 37232.

Address reprint requests to Dr. Blaser at the above address.

Received for publication 22 February 1989 and in revised form 25 October 1989.

J. Clin. Invest.

(c) The American Society for Clinical Investigation, Inc.

0021-9738/90/04/1036/08 $\$ 2.00$

Volume 85, April 1990, 1036-1043 normal human serum and phagocytosis by neutrophils (6-8). This serum- and phagocytosis-resistance is the probable explanation for the high frequency of extraintestinal infection by $C$. fetus.

C. fetus cells contain several surface array proteins (S-proteins) ${ }^{1}$ with molecular weights ranging from 100,000 to 149,000 (9), which form a hexagonal subunit capsular structure on the outer surface of the cell (10). For a given strain, a single protein usually is predominant (9). After repeated in vitro passage, some isolates lose these $\mathrm{S}$-proteins and become unencapsulated, without change in other proteins $(6,7)$. Previous studies of these unencapsulated mutants showed that loss of these high molecular weight S-proteins was associated with loss of resistance to phagocytosis and normal serum killing $(6,7,11)$. To date, correlation of these in vitro results with virulence in an animal model has not been demonstrated.

The aim of this study was to establish an animal model for $C$. fetus infections, and then to determine the importance of the S-proteins in C. fetus virulence. Using a mouse model, we have now been able to: $(a)$ demonstrate that the $\mathrm{LD}_{50}$ of a $C$. fetus wild-type strain is significantly lower than that of its unencapsulated mutant; $(b)$ correlate the presence of S-proteins on $C$. fetus strains with bacteremia after oral challenge; and (c) determine the relative toxicity of the S-protein.

\section{Methods}

Bacterial strains. 14 C. fetus strains from the culture collection of the Denver Veterans Administration Medical Center Campylobacter Laboratory were used in this study. These strains included 12 original isolates from infected humans or animals and two laboratory mutants. The LPS serotyping and the susceptibility of all these strains to the bactericidal activity present in normal human serum had been previously determined $(7,8,12)$. Nine strains contained S-protein, five (84-32, 82-40LP, 84-86, 80-109, and 84-112) were serum resistant ( $\log _{10}$ killing $\left.<0.1\right)$, and four $(84-91,84-94,84-107$, and 84-108) were serum sensitive $\left(\log _{10}\right.$ killing $\left.>1\right)$. Three strains $(81-170,83-88$, and 84-90) were wild-type strains lacking S-proteins and were serum sensitive. Strains 84-54 and 82-40HP were spontaneous mutants of 84-32 and $82-40 \mathrm{LP}$ that lacked S-proteins and were serum sensitive. All strains were maintained frozen at $-70^{\circ} \mathrm{C}$ in brucella broth (BBL Microbiology Systems, Cockeysville, MD) containing $15 \%$ glycerol. For each study, bacteria were grown on trypticase soy agar with 5\% sheep blood (PASCO, Wheat Ridge, CO) in a microaerobic atmosphere $(5 \%$ oxygen, $10 \%$ carbon dioxide, and $85 \%$ nitrogen) at $37^{\circ} \mathrm{C}$ for $48 \mathrm{~h}$ for the first two passages, and for $24 \mathrm{~h}$ for the third passage.

Animals. The experiments were carried out on female HA/ICR mice (Hsd: [ICR] Br; Harlan Sprague Dawley, Inc., Indianapolis, IN), 6-10 wk old, weighing 20-30 g, and on inbred mice, NZB, C57BL/6J (Jackson Laboratory, Bar Harbor, ME), CBA/N, BAlB/c, B6D2F1, $\mathrm{C} 3 \mathrm{H} / \mathrm{HeN}$, and $\mathrm{C} 3 \mathrm{H} / \mathrm{HeJ}$ (Simonsen Laboratory Inc., Gilroy, CA), 10-30 wk old, weighing 20-30 g. Animals were maintained and all studies were performed according to the National Institutes of Health guidelines for small animals.

1. Abbreviations used in this paper: IP, intraperitoneal; S-protein, surface array protein; TSBB, Tris/saline blotting buffer. 
Analytical procedures. Protein concentrations were measured by using the Markwell et al. modification of the Lowry method (13). SDS-PAGE was performed in a modified Laemmli gel system as described by Ames (14). Proteins were resolved using the modified silver stain of Oakley et al. (15). Molecular weight standards (Bio-Rad Laboratories, Richmond, CA) were as follows: myosin $(200,000)$, B-galactosidase $(116,250)$, rabbit muscle phosphorylase B $(92,500)$, BSA $(66,200)$, and hen egg white ovalbumin $(45,000)$. The methods of Towbin et al. (16) formed the basis for the Western blot procedure we used. In brief, SDS-PAGE was performed with a gel thickness of 0.75 $\mathrm{mm}$ in a Mini PROTEAN II dual slab cell (Bio-Rad Laboratories) at $250 \mathrm{~mA}$ for $\sim 40 \mathrm{~min}$. The proteins were then transferred from the slab gel to nitrocellulose paper by electroblotting for $2 \mathrm{~h}$ at $300 \mathrm{~mA}$. The nitrocellulose paper was then blocked twice ( $30 \mathrm{~min}$ each) in Tris/saline blotting buffer (TSBB) (10 mM Tris base, $\mathrm{pH} \mathrm{8.0,0.5} \mathrm{M}$ $\mathrm{NaCl}, 0.5 \%$ Tween $20,0.02 \% \mathrm{NaN}_{3}$ ). The nitrocellulose paper was incubated with a 1:1,000 dilution of serum in TSBB for $40 \mathrm{~min}$. After three washes in TSBB, the nitrocellulose paper was incubated with a 1:5,000 dilution of horseradish peroxidase-conjugated anti-rabbit IgG (Amersham Corp., Arlington Heights, IL). After washing, the nitrocellulose paper was developed in diaminobenzidine solution.

Parenteral challenge. 24-h cultures of $C$. fetus strains 84-32 (S-protein-positive) and 84-54 (S-protein-negative spontaneous mutant) on blood agar plates were harvested in $5 \mathrm{ml}$ of sterile normal saline. Bacterial cells were pelleted at $3,500 \mathrm{~g}$ for $15 \mathrm{~min}$ and resuspended in $0.05 \mathrm{M}$ phosphate buffer with $0.9 \%$ sodium chloride, $\mathrm{pH} 7.4$ (PBS). $\mathrm{HA} / \mathrm{ICR}$ mice were pretreated with 1 or $5 \mathrm{mg}$ of iron as iron dextran or ferric chloride, respectively, or $0.5 \mathrm{ml}$ of normal saline $2 \mathrm{~h}$ before intraperitoneal (IP) challenge with fivefold dilutions of bacterial suspensions originally containing $10^{10} \mathrm{CFU}$ in $0.5 \mathrm{ml}$ normal saline. Mice were observed for death daily for $7 \mathrm{~d}$. The $\mathbf{L D}_{50}$ for each strain was calculated by the method of Reed and Muench (17). A group of 10 HA/ICR mice was pretreated with $5 \mathrm{mg}$ of iron as iron dextran and $2 \mathrm{~h}$ later was intravenously challenged in the tail vein with $10^{8} \mathrm{CFU} C$. fetus strain 84-32. For comparison, another group of 10 mice was challenged intraperitoneally with the same dose of organisms. The mortality of the mice was observed for a 7-d period.

Oral challenge. 20-h cultures of $C$. fetus strains on blood agar were harvested, washed in normal saline, and resuspended in PBS as described above. Each mouse was given $1 \mathrm{mg}$ of iron as ferric chloride by the IP route and $2 \mathrm{~h}$ later was challenged orally with $0.1 \mathrm{ml}$ of bacterial suspension using a 1-in., ball-tipped, 24-gauge animal feeding needle (Popper \& Sons, Inc., New Hyde Park, NY) as previously described (18). Blood samples were collected before challenge and at $0.5,4,24$, 48 , and $120 \mathrm{~h}$ after challenge. Each mouse was anesthetized in a jar with a pad of gauze containing metofane (Pitman-Moore Inc., Washington Crossing, $\mathrm{NJ}$ ) and $200 \mu \mathrm{l}$ of blood was obtained from the retroorbital plexus. For each sample, serial dilutions of blood in normal saline were inoculated onto tryptic soy agar plates with $5 \%$ sheep erythrocytes (PASCO) and incubated microaerobically for $72 \mathrm{~h}$ at $37^{\circ} \mathrm{C}$. Colonies with typical morphology for $C$. fetus were counted to determine the bacterial colony-forming units/milliliter of blood. Five colonies were randomly picked from each positive plate and smeared and stained with carbol fuchsin to determine whether the bacteremia was due to a Campylobacter species.

Passive protection of mice from bacteremia caused by oral challenge with $C$. fetus 84-32. A 24-h culture of $C$. fetus S-plus strain 84-32 was harvested with $0.1 \mathrm{M}$ PBS, pH 7.4. $4 \mathrm{~h}$ before oral challenge, female 10 -wk-old HA/ICR mice were pretreated IP with $10 \mu \mathrm{l}$ of rabbit antiserum to the 100,000 -mol wt S-protein from strain 82-40LP (9), or normal rabbit serum. Both sera had been heated at $56^{\circ} \mathrm{C}$ for $30 \mathrm{~min}$ to inactivate complement. $2 \mathrm{~h}$ before challenge mice were pretreated IP with $1 \mathrm{mg}$ iron as ferric chloride. Oral challenge and subsequent blood cultures were performed as described above.

Toxicity of S-protein. S-protein was extracted with water from strain 84-32 as previously described (9). For quantitation of water-extracted proteins from cells of this S-plus strain, bacteria were harvested from 24-h cultures from 10 blood agar plates, and protein concentra- tions of combined second to fifth water washes (9) and bacterial colony-forming units/milliliter were determined. In total, the amount of protein extracted in this way corresponded to $114 \mu \mathrm{g} / 10^{10} \mathrm{CFU}$. For bacterial challenges, 24-h cultures of strains 84-32 and 84-54 were harvested, washed once with normal saline by centrifugation at $3,500 \mathrm{~g}$ for $15 \mathrm{~min}$, and resuspended in $5 \mathrm{mM}$ of calcium chloride in $10 \mathrm{mM}$ Hepes buffer, pH 7.2. Subsequently, we added 700 or $3,575 \mu \mathrm{g}$ of the water-extracted S-proteins from strain 84-32 or equal amounts of BSA as controls to $10^{10} \mathrm{CFU}$ of 84-54 cells. Thus, the S-proteins were present in 6.1-or 31.1-fold greater concentrations with 84-54 cells than with the 84-32 cells from which they were harvested. The HA/ICR mice were pretreated IP with $1 \mathrm{mg}$ iron as ferric chloride and $2 \mathrm{~h}$ later challenged IP with strain 84-32 or with the mixture of 84-54 and free S-proteins. Mice were observed for mortality over a 7-d period.

\section{Results}

Identification of $S$-proteins in C. fetus strains. Our initial animal studies were performed with the paired strains $84-32$ (23D) and 84-54 (23B), the latter being the spontaneous mutant of the former strain $(7,10)$. Before use in animals, we confirmed by SDS-PAGE and Western blotting that strain 84-32 possessed the S-protein (S-plus), whereas strain 84-54 (S-minus) did not (Figs. 1 and 2). Also shown in the figure are the SDS-PAGE profiles of the other pair of strains 82-40LP (S-plus) and 82-40HP (S-minus), as well as strains 84-86, 80-109, 84-112, 84-91, 84-94, 84-107, and 84-108 (all S-plus), and $81-170,83-88$, and 84-90 (all S-minus) used in later studies. Western blotting with rabbit antiserum against the 100,000-mol wt S-protein of strain 82-40LP (Fig. 2) confirmed both that the S-proteins were present in these strains and that all were antigenically related, except for the 127,000-mol wt S-protein on strain 84-94. No such proteins or fragments were recognized in the S-minus strains.

Effect of pretreatment on susceptibility to peritoneal challenge. Because $C$. fetus is primarily associated with systemic infection in humans, we first challenged mice with organisms delivered by the parenteral route. The wild-type S-plus strain used in these studies was 84-32. After IP challenge of adult HA/ICR mice with up to $1 \times 10^{10}$ live bacteria, no mortality was observed (data not shown). Because iron pretreatment enhances virulence of other bacterial pathogens (19-21), we

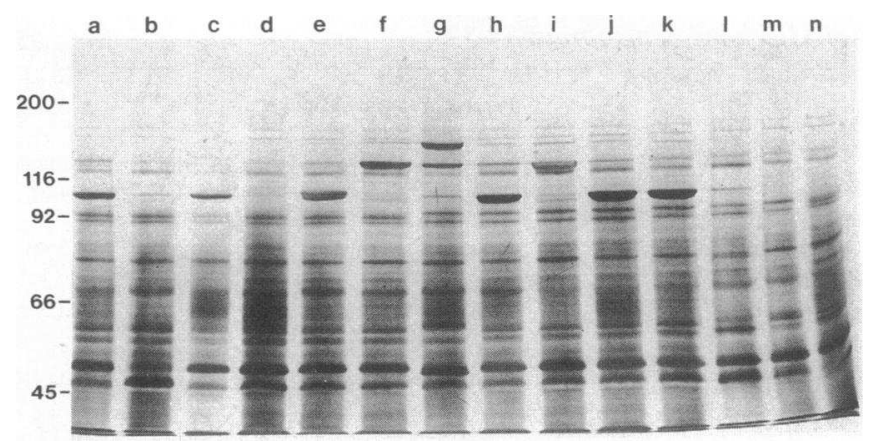

Figure 1. Whole cell proteins of $C$. fetus strains used in this study. SDS-PAGE with 7\% acrylamide. Lane $a, 84-32$; lane $b, 84-54$; lane $c$, 82-40LP; lane $d, 82-40 \mathrm{HP}$; lane $e, 84-86$; lane $f, 80-109$; lane $g$, 84-112; lane $h, 84-91$; lane $i, 84-94$; lane $j, 84-107$; lane $k, 84-108$; lane $l, 81-170$; lane $m, 83-88$; lane $n, 84-90$. Molecular weight markers (in kilodaltons) are shown at left. High molecular weight $(100,000,127,000$, and 149,000$)$ S-proteins are present for the strains represented in lanes $a, c, e$, and $f-k$. 


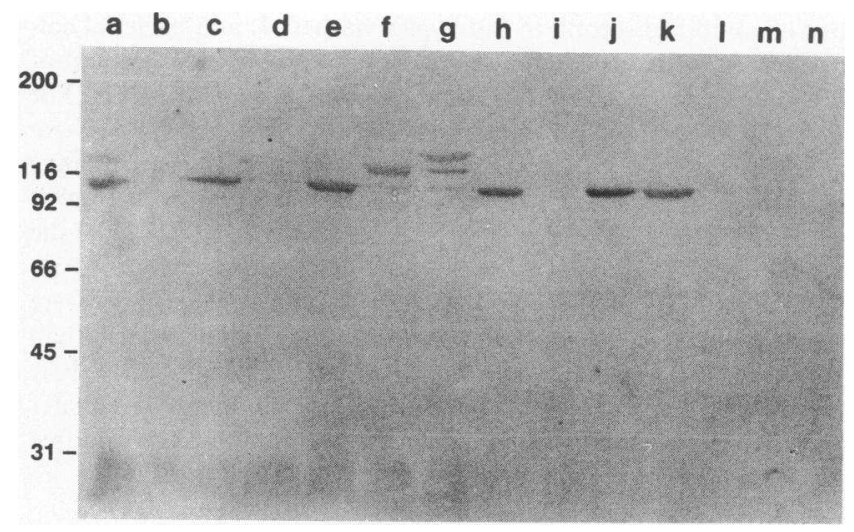

Figure 2. Identification of S-proteins in the whole cell preparation of $C$. fetus strains by immunoblot. Lane $a, 84-32$; lane $b, 84-54$; lane $c$, 82-40LP; lane $d, 82-40 \mathrm{HP}$; lane $e, 84-86$; lane $f, 80-109$; lane $g$, 84-112; lane $h, 84-91$; lane $i, 84-94$; lane $j, 84-107$; lane $k, 84-108$; lane $l, 81-170$; lane $m, 83-88$; lane $n, 84-90$. First antibody is rabbit anti-100,000-mol wt S-protein of strain 82-40LP. High molecular weight S-proteins were identified by crossreaction with $100,000-\mathrm{mol}$ wt S-protein of strain 82-40LP in the western blot in strain 84-32 $(100,000$ and $127,000 \mathrm{~mol} \mathrm{wt})$ (lane $a), 82-40 \mathrm{LP}(100,000 \mathrm{~mol} \mathrm{wt})$ (lane $c), 84-86(100,000 \mathrm{~mol} \mathrm{wt}$ ) (lane $e$ ), 80-109 (127,000 mol wt) (lane $f$ ), 84-112 (127,000 and 149,000 mol wt) (lane $g$ ), 84-91 $(100,000 \mathrm{~mol} \mathrm{wt})$ (lane $h), 84-107(100,000 \mathrm{~mol} \mathrm{wt})($ lane $j)$, and 84-108 (100,000 mol wt) (lane $k$ ). A 127,000-mol wt S-protein present in strain 84-94 as shown by SDS-PAGE (Fig. 1, lane $i$ ) was not recognized by antibody to the $100,000-\mathrm{mol}$ wt S-protein of $82-40 \mathrm{LP}$. S-proteins were not found in mutant strains 84-54 and 82-40HP nor in wild-type strains 81-170, 83-88, and 84-90.

next sought to determine whether a similar phenomenon existed for $C$. fetus infection. We found that after pretreatment with either ferric chloride or iron complexed with dextran, intraperitoneally administered strain 84-32 now caused lethality at doses as low as $1 \times 10^{7} \mathrm{CFU}$ (Table I). No mortality was seen in mice treated with iron compounds without bacterial challenge. The enhancement due to ferric chloride treatment was greater than that due to iron dextran. IP challenge was associated with greater lethality than was intravenous chal-

Table I. Effect of Pretreatment with Iron on Susceptibility of Mice to C. fetus Strain 84-32

\begin{tabular}{|c|c|c|c|c|c|}
\hline \multirow{3}{*}{$\begin{array}{c}\text { Bacterial } \\
\text { dose/mouse }\end{array}$} & \multicolumn{5}{|c|}{ Percent mortality after pretreatment ${ }^{*}$} \\
\hline & \multicolumn{2}{|c|}{ Iron dextran } & \multicolumn{2}{|c|}{ Ferric chloride } & \multirow{2}{*}{$\begin{array}{c}\begin{array}{c}\text { Norma } \\
\text { saline }\end{array} \\
0.5 \mathrm{ml}\end{array}$} \\
\hline & $5 \mathrm{mg}$ & $1 \mathrm{mg}$ & $1 \mathrm{mg}$ & $0.2 \mathrm{mg}$ & \\
\hline $1.6 \times 10^{9}$ & 100 & 40 & 100 & 80 & 0 \\
\hline $1.6 \times 10^{8}$ & 60 & 0 & 100 & 60 & 0 \\
\hline $1.6 \times 10^{7}$ & 0 & 0 & 60 & 0 & ND \\
\hline 0 & 0 & ND & 0 & ND & ND \\
\hline
\end{tabular}

* Iron or saline was administered $2 \mathrm{~h}$ before IP bacterial challenge with bacterial suspensions of S-plus wild-type $C$. fetus strain 84-32 in normal saline. Iron dextran was dosed to yield final concentrations of elemental iron of 5 and $1 \mathrm{mg}$, whereas for ferric chloride dosing to achieve 1 and $0.2 \mathrm{mg}$ was done. Five mice were used for each bacterial dilution and for each condition. Mice were observed for death daily for $7 \mathrm{~d}$. lenge (Table II). Therefore, based on these studies, we used iron pretreatment and IP inoculation for all subsequent parenteral challenges.

Effect of mouse strain on susceptibility to IP challenge. Because large numbers of viable $C$. fetus 84-32 cells were required to kill the outbred HA/ICR mice, we next examined whether inbred mice with defined genetic characteristics might be more susceptible. For six different inbred strains, susceptibility to IP challenge was not measurably different than for HA/ICR mice (Table III). Previous studies have shown that spleen cells from $\mathrm{C} 3 \mathrm{H} / \mathrm{HeJ}$ mice do not respond to challenge with bacterial LPS by showing mitogenic or other immune response, whereas the same cells from $\mathrm{C} 3 \mathrm{H} / \mathrm{HeN}$ mice do respond $(24,25)$. After parenteral challenge with Salmonella species, mortality is higher in the $\mathrm{C} 3 \mathrm{H} / \mathrm{HeJ}$ mice than in $\mathrm{C} 3 \mathrm{H} / \mathrm{HeN}$ mice (25). Since $C$. fetus cells contain LPS with long polysaccharide side-chains (26), it seemed likely that after IP challenge $\mathrm{C} 3 \mathrm{H} / \mathrm{HeJ}$ mice should have a worse outcome than $\mathrm{C} 3 \mathrm{H} / \mathrm{HeN}$ mice (LPS-responder strain). However, we found in repeated experiments that significantly greater mortality occurred in $\mathrm{C} 3 \mathrm{H} / \mathrm{HeN}$ (LPS-responder strain) than in $\mathrm{C} 3 \mathrm{H} / \mathrm{HeJ}$ mice (Table IV) $(P<0.001$, Yates corrected Chisquared test).

$L D_{50}$ in outbred mice. In any event, mortality was no greater in $\mathrm{C} 3 \mathrm{H} / \mathrm{HeN}$ mice than in the outbred $\mathrm{HA} / \mathrm{ICR}$ mice. Therefore, all subsequent studies were performed in HA/ICR mice to compare virulence between an S-plus strain and its spontaneous S-minus mutant. For these experiments a total of 240 mice were used, 10 for each bacterial dilution for each condition. As expected, the $\mathrm{LD}_{50}$ for strain 84-32 (S-plus) was 5.8-fold lower after pretreatment with ferric chloride than after iron dextran (Table V). In both experiments, the $\mathbf{L D}_{50}$ for 84-54 (S-minus) was significantly (15.5- and 43.3-fold) greater than for 84-32 (S-plus). At doses $>10^{9} \mathrm{CFU}$, both strains produced $\sim 100 \%$ mortality, whereas differences in mortality were observed at doses $<10^{9} \mathrm{CFU}$ (Fig. 3). We then examined the time course of mortality after challenge with $3 \times 10^{6}, 1.5$ $\times 10^{7}, 7.5 \times 10^{7}, 3.8 \times 10^{8}$, and $1.9 \times 10^{9} \mathrm{CFU}$ of strains $84-32$ and 84-54 with 10 mice at each dose for each strain. The cumulative percent survival from low dose $\left(3 \times 10^{6}\right)$ to high dose $\left(1.9 \times 10^{9}\right)$ for each strain was calculated against time. For both strains, death rarely occurred before $24 \mathrm{~h}$ or after $72 \mathrm{~h}$ after challenge. Between 24 and 72 h, 29 of 50 mice (58\%) infected with strain 84-32 died, compared with 12 of 50 mice (24\%) infected with strain 84-54 $(P<0.001$, Yates corrected Chi-squared test) (Fig. 4). Thus, the virulence of the S-plus

Table II. Comparison of the Mortality of HA/ICR Mice after IP or Intravenous Challenge with C. fetus Strain 84-32

\begin{tabular}{crc}
\hline & \multicolumn{2}{c}{ Percent mortality* } \\
\cline { 2 - 3 } $\begin{array}{c}\text { Bacterial } \\
\text { dose/mouse }\end{array}$ & IP & Intravenous \\
\hline $9.1 \times 10^{8}$ & 100 & 60 \\
$9.1 \times 10^{7}$ & 50 & 0 \\
$9.1 \times 10^{6}$ & 0 & 0
\end{tabular}

Each mouse was pretreated with $5 \mathrm{mg}$ elemental iron as iron dextran $2 \mathrm{~h}$ before bacterial challenge. 10 mice were used for each bacterial dilution and for each condition.

* Mice were observed for death daily for $7 \mathrm{~d}$. 
Table III. Comparison of Susceptibility of Seven Different Mouse Strains to Lethal Infection Due to C. fetus Strain 84-32

\begin{tabular}{llllllll}
\hline & \multicolumn{3}{c}{ Gene symbols* $^{*}$} & & \multicolumn{2}{c}{ Death at dose } \\
Mouse strain & H-2 & Ity & LPS & & $2 \times 10^{9}$ & $2 \times 10^{7}$ & $2 \times 10^{5}$ \\
\hline HA/ICR & NA & NA & NA & & $3 / 3$ & $0 / 4$ & $0 / 4$ \\
BALB/c & d & s & n & & $3 / 3$ & $0 / 4$ & $0 / 4$ \\
NZB & d & u & n & & $3 / 3$ & $0 / 4$ & $0 / 4$ \\
B6D2F1 & b/d & u & n & & $3 / 3$ & $0 / 4$ & $0 / 3$ \\
C57BL/6J & b & s & n & & $3 / 3$ & $0 / 4$ & $0 / 4$ \\
C3H/HeN & k & r & n & & $3 / 3$ & $0 / 4$ & $0 / 3$ \\
CBA/N & k & r & n & & $2 / 3$ & $0 / 3$ & $0 / 3$ \\
& & & & & & & \\
\hline
\end{tabular}

Each mouse was given intraperitoneally $1 \mathrm{ml}$ bacterial suspension containing $5 \mathrm{mg}$ elemental iron as iron dextran. Mice were observed for mortality for $7 \mathrm{~d}$.

* Gene symbols: $H-2$, HMC in mice; Ity, gene for immunity to $S$. $t y$ phimurium with $r$ and $s$ as the respective resistant and susceptible alleles (22); LPS, gene for responsiveness to toxic and mitogenic effects of LPS with $d$ as defective (nonresponder) and $n$ as normal (responder) alleles (23); $N A$, not applicable for outbred mouse strain; $u$, unknown.

${ }^{\ddagger}$ Number killed/number receiving that dose.

strain was significantly greater than the S-minus strain in this parenteral challenge model.

Oral challenge. Since for humans the presumed route of infection with $C$. fetus is via oral ingestion, we next studied the effects of oral challenge on the HA/ICR mice. After ferric chloride pretreatment, none of 10 mice orally challenged with S-plus strain 84-32 or with its S-minus mutant 84-54 died during a 5-d period. Since in human infections $C$. fetus translocates from the intestinal tract to the bloodstream, we asked whether this phenomenon was related to the presence of the S-protein. Blood cultures from each mouse were obtained before and after oral challenge with strain 84-32 or 84-54. No bacteria were isolated from the blood samples taken before challenge. All five mice challenged with $2 \times 10^{8} \mathrm{CFU}$ of 84-32 showed high-grade bacteremia at $30 \mathrm{~min}, 4 \mathrm{~h}, 24 \mathrm{~h}$, and $48 \mathrm{~h}$

Table IV. Mortality of $\mathrm{C} 3 \mathrm{H} / \mathrm{HeN}$ and $\mathrm{C} 3 \mathrm{H} / \mathrm{HeJ}$ Mice after Challenge with $C$. fetus Strain 84-32

\begin{tabular}{lcc}
\hline & \multicolumn{2}{c}{ Percent death* } \\
\cline { 2 - 3 } Mouse strains & Iron dextran" & Ferric chloridell \\
\hline $\mathrm{C} 3 \mathrm{H} / \mathrm{HeN}$ & 72 & 90 \\
$\mathrm{C} 3 \mathrm{H} / \mathrm{HeJ}$ & 32 & 40 \\
\hline
\end{tabular}

* Significantly greater mortality occurred in $\mathrm{C} 3 \mathrm{H} / \mathrm{HeN}$ than in $\mathrm{C} 3 \mathrm{H} /$ HeJ mice $(P<0.001$, Yates corrected Chi-squared test).

${ }^{\ddagger} \mathrm{C} 3 \mathrm{H} / \mathrm{HeN}$ is a LPS ${ }^{n}$ and Ityr $^{r}$ mouse strain and C3H/HeJ is a LPS and Ity $^{r}$ mouse strain $(22,23)$.

${ }^{8}$ Groups of 25 mice each were pretreated (IP) with $5 \mathrm{mg}$ elemental iron as iron dextran. The cumulative mortality for each mouse strain at doses $10^{7}(n=5), 10^{8}(n=10)$, and $10^{9}(n=10)$ CFU of strain 84-32 was calculated.

"Groups of 10 mice each were pretreated (IP) with $1 \mathrm{mg}$ elemental iron as ferric chloride and then challenged with $3 \times 10^{7} \mathrm{CFU}$ of strain 84-32.
Table V. LD $D_{\text {so }}$ of C. fetus Strains 84-32 and 84-54 after Iron Pretreatment of Adult HA/ICR Mice

\begin{tabular}{lcc}
\hline & \multicolumn{2}{c}{ LD $_{\text {so }}$} \\
\cline { 2 - 3 } \multicolumn{1}{c}{ Bacterial strain } & Iron dextran & Ferric chloride* \\
\hline S-plus (84-32) & $7.6 \times 10^{8}$ & $1.3 \times 10^{7}$ \\
S-minus (84-54) & $1.2 \times 10^{10}$ & $5.5 \times 10^{8}$ \\
Ratio (84-54/84-32) & 15.5 & 43.3
\end{tabular}

Groups of 10 mice each were given from $10^{5}$ to $10^{10} \mathrm{CFU}$ of wildtype S-plus $C$. fetus strain 84-32 or its spontaneous mutant S-minus strain 84-54.

* $5 \mathrm{mg}$ elemental iron as iron dextran or $1 \mathrm{mg}$ elemental iron as ferric chloride was administered intraperitoneally $2 \mathrm{~h}$ before IP challenge of adult HA/ICR mice with bacterial suspensions of strain 84-32 or 84-54. Mice were observed for death daily for $7 \mathrm{~d}$.

after challenge and became negative between 48 and $120 \mathrm{~h}$. In contrast, $C$. fetus was not isolated from any mice challenged with a similar dose of 84-54 at any time after injection (Table VI). The absence of bacteremia in mice challenged with Sminus strain 84-54 indicated that bacteremia did not result from trauma to the upper gastrointestinal tract during the feeding. To determine whether the presence of the S-protein permitted bacteremia by $C$. fetus, we separately challenged HA/ICR mice with five S-plus and serum-resistant $C$. fetus strains, four S-plus but serum-sensitive strains, or five S-minus and serum-sensitive strains including three wild-type strains and two spontaneous mutants and tested bacteremia $4 \mathrm{~h}$ after challenge (Table VII). The nine S-plus strains tested, regardless of serum susceptibility or LPS type, caused bacteremia in $\mathbf{4 0}$ of $45(88.8 \%)$ mice $4 \mathrm{~h}$ after oral challenge, whereas none of 25 mice challenged with five S-minus strains were bacteremic $(P$ $<0.001$, Yates corrected chi-square test). We next questioned whether iron pretreatment was necessary for $C$. fetus to cause bacteremia in HA/ICR mice. Bacteremia after challenge with $2 \times 10^{7}-7 \times 10^{8}$ CFU of S-plus strain 84-32 occurred in 4 of 8 mice pretreated with iron, 5 of 8 mice pretreated with normal saline, and none of 6 mice challenged with S-minus strain 84-54. From these studies we concluded that the presence of an S-protein was associated with bacteremia after oral challenge, regardless of iron pretreatment, serum susceptibility, or LPS type of the challenge strain.

Passive protection of $H A / I C R$ mice from bacteremia after oral challenge. Three groups of seven mice each were challenged orally with $1.1 \times 10^{9}(n=2)$ or $1.5 \times 10^{9}(n=5)$ CFU of

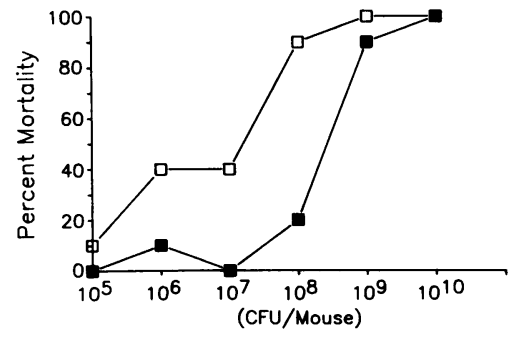

Figure 3. Dose-dependent mortality of mice challenged with $C$. fetus strain $84-32$ or $84-54$. 10 mice were each given $1 \mathrm{mg}$ iron as ferric chloride intraperitoneally $2 \mathrm{~h}$ before challenge with $C$. fetus strain 84-32 (open

squares) or 84-54 (solid squares) and observed for death for $7 \mathrm{~d}$. No difference was found at doses $>10^{9} \mathrm{CFU}$, but at $10^{8} \mathrm{CFU}$ S-plus strain $84-32$ caused $70 \%$ more mortality than its S-minus mutant strain 84-54. 


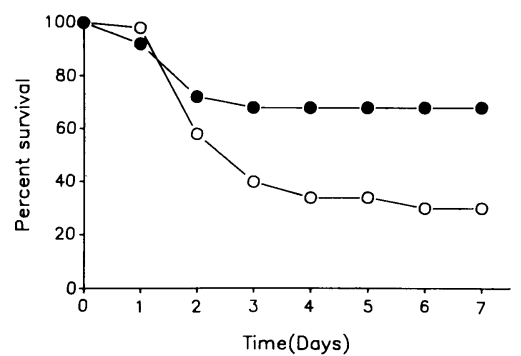

Figure 4. Survival of HA/ICR mice after IP challenge with $C$. fetus S-minus strain 84-54 (solid circles) or S-plus strain 84-32 (open circles). 50 adult HA/ICR mice were each given 1 $\mathrm{mg}$ iron as ferric chloride intraperitoneally 2 $\mathrm{h}$ before challenge. Five doses of serial 1:5 dilutions of an inoculum of $2 \times 10^{9} \mathrm{CFU}$ of $C$. fetus cells were used for of challenge of 10 mice at each dose for each strain. A cumulative percent survival over time was calculated based on the mortality from the five doses for each strain. Most mortality was observed between 24 and $72 \mathrm{~h}$ for both strain 84-32 (58\%) and strain $84-54(24 \%)$.

C. fetus strain 84-32. Each mouse was pretreated with $10 \mu \mathrm{l}$ of rabbit antiserum to $100,000-\mathrm{mol}$ wt purified S-protein, normal rabbit serum, or normal saline as controls. Blood cultures were performed on samples taken at $30 \mathrm{~min}, 4 \mathrm{~h}, 12 \mathrm{~h}$, and $24 \mathrm{~h}$ after oral challenge. Immune serum to the $100,000-\mathrm{mol}$ wt S-protein was highly protective compared with normal rabbit serum and the normal saline control (Fig. 5). These results support the hypothesis that the S-proteins play an important role in virulence.

Toxicity of S-protein. A group of 10 mice was intraperitoneally challenged with one of two suspensions of strain 84-54, containing either 6.1- or 31.1-fold more S-protein than found on strain 84-32. As expected, IP injection of $4 \times 10^{6}-4 \times 10^{7}$ CFU of S-plus strain 84-32 caused $80 \%$ mortality in the ironpretreated mice, whereas $\mathrm{S}$-minus strain $84-54$ caused none (Table VIII). Suspension of strain 84-54 in a solution containing S-proteins at a 6.1-fold excess over that associated with strain 84-32 caused no mortality, but at a 31.1-fold excess $30 \%$ mortality was observed. S-protein alone or strain 84-54 with BSA were administered as controls and were associated with

Table VI. Bacteremia in Adult HA/ICR Mice after Oral Challenge with C. fetus

\begin{tabular}{crc}
\hline & \multicolumn{2}{c}{$\begin{array}{c}\text { Log }_{10} \mathrm{CFU} / \mathrm{ml} \text { blood* } \\
(\mathrm{mean} \pm \mathrm{SD})\end{array}$} \\
\cline { 2 - 3 } Time & S-plus 84-32 & S-minus 84-54 \\
\hline$h$ & & \\
0 & $<1.0 \pm 0.0$ & $<1.0 \pm 0.0$ \\
0.5 & $4.2 \pm 0.2$ & $<1.0 \pm 0.0$ \\
4 & $4.1 \pm 0.3$ & $<1.0 \pm 0.0$ \\
24 & $3.2 \pm 0.2$ & $<1.0 \pm 0.0$ \\
48 & $4.1 \pm 0.6$ & $<1.0 \pm 0.0$ \\
120 & $<1.0 \pm 0.0$ & $<1.0 \pm 0.0$ \\
& &
\end{tabular}

Five mice were used in each group. Each mouse was given $1 \mathrm{mg}$ elemental iron as ferric chloride $2 \mathrm{~h}$ before oral challenge with $1.9 \times 10^{8}$ CFU of strain 84-32 or with $2 \times 10^{8} \mathrm{CFU}$ of strain 84-54.

* Sensitivity of assay: blood culture detects 10 bacterial CFU/ml blood. Between 0.5 and $48 \mathrm{~h}$ after challenge with S-plus strain 84-32 each mouse sampled was bacteremic at times, whereas none of the mice challenged with S-minus strain 84-54 were bacteremic at any time. no mortality. To investigate whether the S-proteins are nonspecific virulence factors or only enhance virulence of $C$. fetus strains, we attempted to attach the S-proteins to Campylobacter jejuni strain 81-176. In the presence of $5 \mathrm{mM} \mathrm{CaCl}_{2}$, the S-protein readily attached to $C$. fetus strain 84-54 and remained attached as visualized by SDS-PAGE (data not shown) despite three successive washes in Hepes buffer ( $\mathrm{pH}$ 7.2) with 5 $\mathrm{mM} \mathrm{CaCl}{ }_{2}$. In contrast, under the same conditions we could not produce any attachment to the $C$. jejuni strain. As such, we were unable to perform virulence studies with the combination of S-protein and a non-C. fetus strain of low virulence. These experiments suggest that $C$. fetus strains may have specific receptors for the S-proteins.

\section{Discussion}

The results of this study demonstrate a correlation between the presence of S-proteins and virulence of $C$. fetus strains. A strain encapsulated with $\mathrm{S}$-proteins has a lower $\mathrm{LD}_{50}$ value for IP challenge in mice than its unencapsulated mutant strain, and encapsulated strains are able to penetrate the gastrointestinal mucosa after oral challenge, causing bacteremia and systemic infection.

The IP challenge model could be considered as artificial because of iron pretreatment and high dose of $C$. fetus. However, $C$. fetus is an opportunistic pathogen of humans. Most hosts with systemic $C$. fetus infections are compromised by liver disease, neoplasia, or immunosuppression (7); iron pretreatment serves an analogous function in the experimental model. Similar to humans, normal mice are resistant to $C$. fetus, even at doses as high as $10^{10} \mathrm{CFU}$, but become susceptible after compromise (in this case, iron pretreatment). High dose is necessary because this organism is an opportunistic pathogen that is not as virulent as Salmonella typhi to humans or Salmonella typhimurium to mice. The IP challenge model resembles an endotoxemia model. However, it is a infection model as well, despite lack of direct evidence of replication of organisms in the peritoneal cavity and spread to the reticuloendothelial system. In earlier work we showed a significantly greater increase in splenic size after IP challenge with the Splus strain than the S-minus strain (Blaser, M. J., and D. J. Duncan, unpublished data). In our experiment to protect mice from lethal IP challenge with S-plus strain $84-32,70 \%$ of mice were protected with antiserum to S-protein compared with $30 \%$ protected with antiserum to the heat-stable $\mathrm{O}$ antigen (mostly LPS) of same bacteria (Pei, Z., and M. J. Blaser, unpublished data). In this model, most mice died between 24 and $72 \mathrm{~h}$ after challenge, similar to that observed with endotoxemia. A typical endotoxemia model would not differentiate an S-plus strain from an S-minus strain when mice are challenged with the same doses of bacteria and thus LPS (26); however, the $C$. fetus IP challenge model that we used clearly did so.

Iron is essential for the growth of essentially all bacteria $(27,28)$, and iron overload appears to be a risk factor for systemic $C$. fetus infection in humans (1-4). The growth of pathogenic bacteria in vivo depends on their ability to obtain iron bound by host substances, such as transferrin and lactoferrin (29-32). Most aerobic bacteria produce siderophores, high-affinity compounds that bind, solubilize, and transport iron across the cell membrane $(33,34)$, but none are produced by Campylobacter species (35). Iron-containing compounds such as mucin, iron dextran, and ferric chloride have been 


\begin{tabular}{|c|c|c|c|c|c|c|}
\hline Strain & Source & $\begin{array}{c}\text { Major } \\
\text { S-protein }\end{array}$ & LPS type* & Serum killing ${ }^{*}$ & Challenge dose & Bacteremia" \\
\hline $84-32$ & Bovine vagina & 100,000 & A & $<0.05$ & $2 \times 10^{8}$ & $5 / 5$ \\
\hline $82-40 \mathrm{LP}$ & Human blood & 100,000 & A & $<0.05$ & $1 \times 10^{9}$ & $5 / 5$ \\
\hline $84-86$ & Human blood & 100,000 & A & $<0.05$ & $4 \times 10^{7}$ & $3 / 5$ \\
\hline $80-109$ & Human blood & 127,000 & $\mathbf{A}$ & $<0.05$ & $1 \times 10^{8}$ & $5 / 5$ \\
\hline $84-112$ & Bovine genital & 149,000 & A & 0.06 & $1 \times 10^{6}$ & $4 / 5$ \\
\hline $84-91$ & Human blood & 100,000 & $\mathbf{A B}$ & 2.96 & $2 \times 10^{9}$ & $5 / 5$ \\
\hline $84-94$ & Human blood & 127,000 & $\mathbf{A B}$ & 2.70 & $1 \times 10^{8}$ & $3 / 5$ \\
\hline $84-107$ & Human blood & 100,000 & B & 2.71 & $5 \times 10^{8}$ & $5 / 5$ \\
\hline $84-108$ & Human blood & 100,000 & B & 2.56 & $5 \times 10^{8}$ & $5 / 5$ \\
\hline $81-170$ & Bovine & - & B & 2.50 & $2 \times 10^{8}$ & $0 / 5$ \\
\hline $83-88$ & Human blood & - & B & 1.63 & $1 \times 10^{8}$ & $0 / 5$ \\
\hline $84-90$ & Bovine fetus & - & B & 3.93 & $8 \times 10^{8}$ & $0 / 5$ \\
\hline $84-54$ & Laboratory mutant & - & A & 2.10 & $2 \times 10^{8}$ & $0 / 5$ \\
\hline $82-40 \mathrm{HP}$ & Laboratory mutant & - & A & 1.02 & $4 \times 10^{9}$ & $0 / 5$ \\
\hline
\end{tabular}

Each mouse was pretreated with $1 \mathrm{mg}$ elemental iron as ferric chloride IP $2 \mathrm{~h}$ before oral challenge and checked for bacteremia $4 \mathrm{~h}$ after challenge. ${ }^{*}$ LPS serotype determined as described $(7,12)$. ${ }^{\ddagger}$ Serum killing is expressed in $\log _{10}$. Data are from reference 7 . "Number with bacteremia detected/number receiving that dose.

used to enhance the virulence of Neisseria (20), Vibrio (21), Campylobacter (19), and other species. In the present study, the virulence of $C$. fetus strains was enhanced at least 100 -fold by pretreatment of mice with iron dextran or ferric chloride. Although the mechanisms by which iron compounds increase susceptibility to $C$. fetus infection were not determined, saturation of transferrin, or impaired murine macrophage function may have been factors (36-39).

Several lines of evidence suggest that the $C$. fetus S-proteins are not toxic per se but enhance virulence when present on bacterial cell surfaces as a capsule. (a) The $\mathrm{LD}_{50}$ for encapsulated strain 84-32 is significantly lower than its unencapsulated mutant 84-54. (b) After oral challenge, encapsulated strains are able to cause bacteremia, while unencapsulated strains are not,

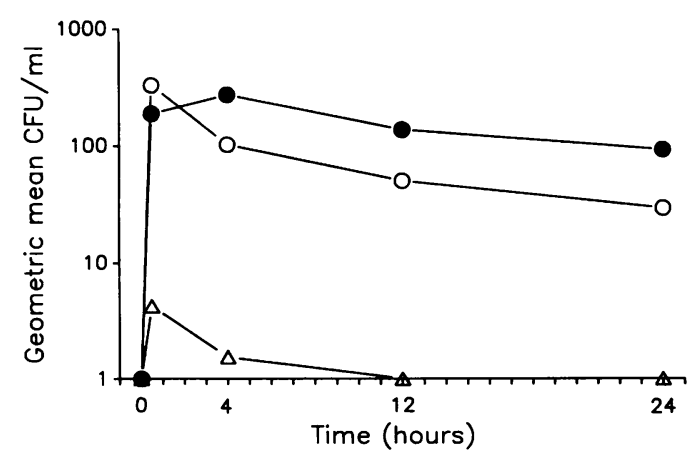

Figure 5. Passive protection of HA/ICR mice from bacteriemia after oral challenge. Three groups of seven mice each were passively immunized with $10 \mu \mathrm{l}$ of antiserum to 100,000-mol wt S-protein (open triangles), normal rabbit serum (solid circles), or normal saline (open circles) $4 \mathrm{~h}$ before oral challenge with $1.1 \times 10^{9}(n=2)$ or $1.5 \times 10^{9}$ $(n=5)$ CFU of S-plus strain 84-32. Blood cultures were performed before or at $0.5,4,12$, and $24 \mathrm{~h}$ after challenge. Geometric mean colony-forming units/milliliter of blood was plotted against time. Bacteremia in mice pretreated with anti-S-protein serum was signifcantly lower than in controls. regardless of serum susceptibility. (c) High concentrations of free S-protein mixed with an unencapsulated strain enhance its virulence. $(d)$ other studies in our laboratory have shown that removal of the S-protein coat from the surface of strain 84-32 using pronase results in a 40-fold $\mathrm{LD}_{50}$ increase, similar to that caused by the S-protein-deficient mutant 84-54 (40). (e) Finally, the evidence that these S-proteins are virulence determinants was further strengthened by the passive protection of HA/ICR mice with antiserum to S-protein from highdegree bacteremia after oral challenge. Our previous in vitro work indicates that one of the mechanisms by which the Sprotein capsule protects $C$. fetus is via its inhibition of $\mathrm{C} 3 \mathrm{~b}$ binding, preventing immune elimination (11).

Oral challenge of mice with $C$. fetus provides a relevant model for study of human infection. The ability to cause bacteremia after oral challenge was related only to the presence of S-proteins, not to iron pretreatment, LPS type, or the susceptibility of $C$. fetus strains to killing by normal serum. S-plus $C$. fetus strains can apparently penetrate the intestinal wall and produce bacteremia lasting $48-120 \mathrm{~h}$ after oral challenge. The mechanism for this penetration has not been determined, but it is clearly rapid in onset. Although no illness or mortality was observed as a result of bacteremia, we might expect longerlasting bacteremia, morbidity, and even mortality in orally challenged immunocompromised mice, similar to that observed in compromised humans $(1,3,4)$.

Immunocompromise is a prerequisite for $C$. fetus to cause systemic infection in humans $(1,3,4)$, suggesting that immune function is highly related to host susceptibility to $C$. fetus infection. Most S-plus strains are resistant to in vitro killing by normal serum, but exceptions have been noted $(7,8)$. Such strains are encapsulated with S-proteins but have type B LPS instead of the type A LPS usually present in serum-resistant strains. Comparing these strains with S-plus strains containing type A LPS, we expected to find that the serum-resistant strains would cause bacteremia, whereas the serum-sensitive strains would not. However, our results clearly showed that 
Table VIII. Effect of Adding S-proteins to S-minus C. fetus Cells in Relation to Virulence after Parenteral Challenge

\begin{tabular}{|c|c|c|c|c|}
\hline Strain & $\begin{array}{l}\text { No. of mice } \\
\text { challenged }\end{array}$ & Treatment* & Dose & Mortality ${ }^{\ddagger}$ \\
\hline & & & CFU/mouse & $\%$ \\
\hline $84-32$ & 20 & None & $4.0 \times 10^{6}-4.0 \times 10^{7}$ & 85 \\
\hline $84-54$ & 20 & None & $9.1 \times 10^{6}-9.1 \times 10^{7}$ & 0 \\
\hline $84-54$ & 20 & BSA $(0.9-25 \mu \mathrm{g})$ & $8.0 \times 10^{6}-8.0 \times 10^{7}$ & 0 \\
\hline $84-54$ & 10 & S-protein $(0.9-9 \mu \mathrm{g})$ & $1.3 \times 10^{7}-1.3 \times 10^{8}$ & 0 \\
\hline $84-54$ & 10 & S-protein $(25 \mu \mathrm{g})$ & $7 \times 10^{7}$ & 30 \\
\hline None & 7 & S-protein $(25 \mu \mathrm{g})$ & - & 0 \\
\hline
\end{tabular}

Mice were pretreated with $1 \mathrm{mg}$ elemental iron as iron dextran $2 \mathrm{~h}$ before challenge with bacteria. ${ }^{*}$ Treatment was performed by dilution of S-minus strain 84-54 in buffer containing S-proteins from strain 84-32 at 6.1-fold (0.9-9 $\mu \mathrm{g} / \mathrm{mouse})$ or 31.1-fold (25 $\mu \mathrm{g} / \mathrm{mouse}) \mathrm{more}$ than usually are complexed to strain 84-32 as determined by S-protein/cell ratio (see Methods). Strain 84-54 was suspended in equivalent amounts of BSA as control. The high dose $(25 \mu \mathrm{g})$ of S-protein alone was administered to determine whether it was independently toxic. ${ }^{\ddagger}$ Mice were observed for death daily for $7 \mathrm{~d}$.

encapsulated $C$. fetus strains caused bacteremia after oral challenge, regardless of serum sensitivity. Thus, serum susceptibility may be an imperfect marker for virulence of $C$. fetus strains. The S-plus $C$. fetus strains with type B LPS may have a virulence mechanism different from that of the type A LPS strains.

To find mouse strains more susceptible to C. fetus infection, we compared an outbred and six inbred mouse strains with different H-2, Ity, and LPS-response genes. Susceptibility of mice to C. fetus infection was independent of $\mathrm{H}-2$ and Ity genes. However, by comparing paired LPS ${ }^{d}$ mice $(\mathrm{C} 3 \mathrm{H} / \mathrm{HeJ})$ and LPS $^{n}$ mice $(\mathrm{C} 3 \mathrm{H} / \mathrm{HeN})$, we found that susceptibility was linked to LPS responsiveness, which is independent of Ity status (22). $\mathrm{C} 3 \mathrm{H} / \mathrm{HeJ}$ mice are defective in their response to most biological effects of LPS $(41-45)$ due to a mutation at the LPS gene locus on chromosome 4 (25). The $\mathrm{LD}_{50}$ of $S$. typhimurium is $<2 \mathrm{CFU}$ in $\mathrm{LPS}^{\mathrm{d}} \mathrm{C} 3 \mathrm{H} / \mathrm{HeJ}$ mice and $10^{3}-10^{4} \mathrm{CFU}$ in LPS $^{n} \mathrm{C} 3 \mathrm{H} / \mathrm{HeN}$ mice (22). In contrast to these observations, greater mortality was found in LPS $^{n} \mathrm{C} 3 \mathrm{H} / \mathrm{HeN}$ mice challenged with S-plus $C$. fetus than in LPS $\mathbf{C} 3 \mathrm{H} / \mathrm{HeJ}$ mice (Table IV). The LPS gene controls both susceptibility to the toxic effects of LPS and specific and more generalized immunoregulatory responses to LPS $(25,41-45)$. Defects in the LPS gene of $\mathrm{C} 3 \mathrm{H} / \mathrm{HeJ}$ mice render them resistant to endotoxic shock after challenge with purified LPS at concentrations that are lethal to other $\mathrm{C} 3 \mathrm{H}$ lineages and unresponsive to the immunostimulatory effects of LPS $(25,41-45)$. C. fetus is a pathogen adapted to the bovine and ovine species, and is clearly much less virulent in mice than $S$. typhimurium with significantly higher $\mathrm{LD}_{50} \mathrm{~S}$ even for the more virulent S-plus strain. However, $C$. fetus LPS has endotoxic activity similar to that of the Enterobacteriaceae (26). As evidenced by the temporal characteristics of $C$. fetus-induced lethality, the toxic effects of LPS may be important virulence factors, whereas LPS at the challenge level may have minimal toxic effects in $S$. typhimurium-infected mice. In the present study, relative resistance of $\mathrm{C} 3 \mathrm{H} / \mathrm{HeJ}$ mice to the toxic effects of LPS is the most likely factor responsible for their lower susceptibility than $\mathrm{C} 3 \mathrm{H} / \mathrm{HeN}$ mice to $C$. fetus infection.

In conclusion, we have described a mouse model of $C$. fetus infection that is relevant to human infection. The presence of $\mathrm{S}$-proteins is an important virulence factor after parenteral or oral challenge of these animals. These in vivo studies raise a number of interesting questions relating to the mechanisms by which encapsulated $C$. fetus strains cause disease, such as the role of iron in $C$. fetus infection, differences between S-proteins from $C$. fetus strains with type A LPS or type B LPS, and how S-proteins enable $C$. fetus to penetrate the intestinal wall and cause systemic infection.

\section{Acknowledgments}

This work was supported in part by the U. S. Army Medical Research and Development Command, by the Medical Research Service of the Veterans Administration, and by the National Institute of Allergy and Infectious Disease (R01 AI-24145-01A1). Dr. Blaser is a Clinical Investigator of the Veterans Administration.

\section{References}

1. Guerrant, R. L., G. R. Lahita, W. C. Winn, Jr., and R. B. Roberts. 1978. Campylobacterosis in man: pathogenic mechanisms and review of 91 blood stream infections. Am. J. Med. 65:584-592.

2. Blaser, M. J., and L. B. Reller. 1981. Campylobacter enteritis. $N$. Engl. J. Med. 305:1444-1452.

3. Bokkenheuser, V. 1970. Vibrio fetus infection in man. I. Ten new cases and some epidemiologic observations. Am. J. Epidemiol. 91:400-409.

4. Francioli, P., J. Herzstein, J.-P. Grob, J.-J. Vallotton, G. Mombelli, and M. P. Glauser. 1985. Campylobacter fetus subspecies fetus bacteremia. Arch. Intern. Med. 145:289-292.

5. Klein, B. S., J. M. Vergeront, M. J. Blaser, P. Edmonds, D. Brenner, D. Janssen, and J. P. Davis. 1986. An outbreak of Campylobacter jejuni and thermotolerant Campylobacter fetus subsp. fetus associated with raw milk. JAMA (J. Am. Med. Assoc.). 255:361-364.

6. McCoy, E. C., D. Doyle, K. Burda, L. B. Corbell, and A. J. Winter. 1975. Superficial antigens of Campylobacter (Vibrio) fetus: characterization of an antiphagocytic component. Infect. Immun. 517-525.

7. Blaser, M. J., P. F. Smith, J. A. Hopkins, I. Heinzer, J. H. Bryner, and W.-L. L. Wang. 1987. Pathogenesis of Campylobacter fetus infections: serum resistance associated with high-molecular-weight surface proteins. J. Infect. Dis. 155:696-706.

8. Blaser, M. J., P. F. Smith, and P. F. Kohler. 1985. Susceptibility of Campylobacter isolates to the bactericidal activity of human serum. J. Infect. Dis. 151:227-235. 
9. Pei, Z., R. T. Ellison III, R. V. Lewis, and M. J. Blaser. 1988. Purification and characterization of a family of high molecular weight surface-array proteins from Campylobacter fetus. J. Biol. Chem. 263:6416-6420.

10. McCoy, E. C., H. A. Wiltberger, and A. J. Winter. 1976. Major outer membrane protein of Campylobacter fetus: physical and immunological characterization. Infect. Immun. 13:1258-1265.

11. Blaser, M. J., P. F. Smith, J. E. Repine, and K. A. Joiner. 1988. Pathogenesis of Campylobacter fetus infections. Failure of encapsulated Campylobacter fetus to bind $\mathrm{C} 3 \mathrm{~b}$ explains serum and phagocytosis resistance. J. Clin. Invest. 1434-1444.

12. Perez, G. I., M. J. Blaser, and J. H. Bryner. 1986. Lipopolysaccharide structures of Campylobacter fetus are related to heat-stable serogroups. Infect. Immun. 51:209-212.

13. Markwell, M. A. K., S. M. Haar, L. L. Bieber, and N. E. Tolbert. 1978. A modification of the Lowry procedure to simplify protein determination in membrane and lipoprotein samples. Anal. Biochem. 87:206-210.

14. Ames, G. F. L. 1974. Resolution of bacterial proteins by polyacrylamide gel electrophoresis on slabs. J. Biol. Chem. 249:634-644.

15. Oakley, B. R., D. R. Kirsch, and N. R. Morris. 1980. A simplified ultrasensitive silver stain for detecting proteins in polyacrylamide gels. Anal. Biochem. 105:361-363.

16. Towbin, H., T. Staehelin, and J. Gordon. 1979. Electrophoretic transfer of proteins from polyacrylamide gel to nitrocellulose sheets: procedure and some applications. Proc. Natl. Acad. Sci. USA. 76:4350-4354.

17. Reed, L. J., and H. A. Muench. 1938. A simple method of estimating fifty percent end points. Am. J. Hyg. 27:493-497.

18. Blaser, M. J., D. J. Duncan, G. H. Warren, and W.-L. L. Wang. 1983. Experimental Campylobacter jejuni infection of adult mice. Infect. Immun. 39:908-916.

19. Kazmi, S. U., B. S. Roberson, and N. J. Stern. 1984. Animalpassed, virulence-enhanced Campylobacter jejuni causes enteritis in neonatal mice. Curr. Microbiol. 11:159-164.

20. Calver, G. A., C. P. Henney, and G. Lavergne. 1976. Iron as a replacement for mucin in the establishment of meningococcal infection in mice. Can. J. Microbiol. 22:832-838.

21. Eubanks, E. R., M. N. Guentzl, and L. J. Berry. 1976. Virulence factors involved in the intraperitoneal infection of adult mice with Vibrio cholerae. Infect. Immun. 13:457-463.

22. O'Brien, A. D., D. L. Rosenstreich, I. Scher, G. H. Campbell, R. P. MacDermott, and S. B. Formal. 1980. Genetic control of susceptibility to Salmonella typhimurium in mice: role of the LPS gene. $J$. Immunol. 124:20-24.

23. Watson, J., K. Kelly, M. Largen, and B. A. Taylor. 1978. The genetic mapping of a defective LPS response gene in $\mathrm{C} 3 \mathrm{H} / \mathrm{HeJ}$ mice. $J$. Immunol. 120:422-424.

24. Von Jeney, N., E. Gunther, and K. Jann. 1977. Mitogenic stimulation of murine spleen cells: relation to susceptibility to Salmonella infection. Infect. Immun. 15:26-33.

25. O'Brien, A. D., D. A. Weinstein, M. Y. Soliman, and D. L. Rosenstreich. 1985. Additional evidence that the LPS gene locus regulates the natural resistance to $S$. typhimurium in mice. J. Immunol. $134: 2820-2823$
26. Perez, G. I., and M. J. Blaser. 1985. Lipopolysaccharide characteristics of pathogenic campylobacters. Infect. Immun. 47:353-359.

27. Neilands, J. B. 1981. Microbial iron compounds. Annu. Rev. Biochem. 50:715-731.

28. Weinberg, E. D. 1978. Iron and infection. Microbiol. Rev. 42:45-66.

29. Bullen, M. 1974. Iron and infection. In Iron in Biochemistry and Medicine. A. Jacobs and M. Worwood, editors. Academic Press, Inc., New York. 649-679.

30. Kochan, I. 1973. The role of iron in bacterial infections with special consideration of host-tubercle bacillus interaction. Curr. Top. Microbiol. Immunol. 60:1-30.

31. Milles, A. A., and P. L. Khiji. 1975. Enterobacterial chelators of iron: their occurrence, detection, and relation to pathogenicity. J. Med. Microbiol. 8:477-490.

32. Weinberg, E. D. 1971. Role of iron in host-parasite interactions. J. Infect. Dis. 124:401-410.

33. Lankford, C. E. 1973. Bacterial assimilation of iron. Crit. Rev. Microbiol. 2:273-331.

34. Luckey, M., J. R. Pollack, R. Wayne, B. N. Ames, and J. B. Neilands. 1972. Iron uptake in Salmonella typhimurium: utilization of exogenous siderochromes as iron carriers. J. Bacteriol. 111:731-738.

35. Baig, B. H., I. K. Wachsmuth, and G. K. Morris. 1986. Utilization of exogenous siderophores by Campylobacter species. J. Clin. Microbiol. 23:431-433.

36. Kochan, I., J. Wasynezuk, and M. A. McCabe. 1978. Effects of injected iron and siderophores on infections in normal and immune mice. Infect. Immun. 22:560-567.

37. Kochan, I., C. A. Golden, and J. A. Buckovic. 1969. Mechanisms of tuberculosis in mammalian serum. II. Induction of serum tuberculosis in guinea pigs. J. Bacteriol. 600:64-70.

38. Weinberg, E. D. 1974. Iron and susceptibility to infectious disease. Science (Wash. DC). 184:952-956.

39. Suveges, I., and R. Glavits. 1976. Piglet losses due to parenteral application of iron dextran preparation. Acta. Vet. Acad. Sci. Hung. 26:257-262.

40. Blaser, M. J., P. F. Smith, and Z. Pei. 1987. Role of high molecular weight surface proteins in serum and phagocytosis-resistance of Campylobacter fetus. 27th Intersci. Conf. Antimicrobial Agents and Chemother. Am. Soc. Microbiol. 327. (Abstr.)

41. Sultzer, B. M. 1968. Genetic control of leukocyte responses to endotoxin. Nature (Lond.). 219:1253-1254.

42. Glode, L. M., S. E. Mergenhagen, and D. L. Rosenstreich. 1976. Significant contribution of spleen cells in mediating the lethal effects of endotoxin in vivo. Infect. Immun. 14:626-630.

43. Watson, J., and R. Riblet. 1974. Genetic control of response to bacterial lipopolysaccharides in mice. Evidence for a single gene that influences mitogenic and immunogenic responses to lipopolysaccharides. J. Exp. Med. 140:1147-1161.

44. Chedid, L., M. Parant, C. Damais, F. Parant, D. Juy, and A. Galelli. 1975. Failure of endotoxin to increase nonspecific resistance to infection of lipopolysaccharide low-responder mice. Infect. Immun. 13:722-727.

45. Glode, L. M., A. Jacques, S. E. Mergenhagen, and D. L. Rosenstreich. 1977. Resistance of macrophages from $\mathrm{C} 3 \mathrm{H} / \mathrm{HeJ}$ mice to the in vitro cytotoxic effects of endotoxin. J. Immunol. 119:162-166. 